\title{
Role of human papillomavirus infection in the etiology of vulvar cancer in Italian women
}

\author{
Mario Preti ${ }^{1}$, John Charles Rotondo ${ }^{2,3}$, Dana Holzinger ${ }^{4}$, Leonardo Micheletti ${ }^{1}$, Niccolò Gallio ${ }^{1}$, \\ Sandrine McKay-Chopin ${ }^{2}$, Christine Carreira ${ }^{2}$, Sebastiana Silvana Privitera ${ }^{5}$, Reiko Watanabe ${ }^{2}$, Ruediger Ridder ${ }^{6,7}$, \\ Michael Pawlita ${ }^{4}$, Chiara Benedetto ${ }^{1}$, Massimo Tommasino ${ }^{2}$ and Tarik Gheit ${ }^{2 *}$
}

\begin{abstract}
Background: Vulvar squamous cell carcinoma (VSCC) is a rare malignancy of the female genital tract. We aimed to determine the mucosal high-risk human papillomavirus (HPV)-attributable fraction of VSCCs from Italian women using multiple markers of viral infections.

Methods: VSCCS and 8 metastatic lymph node samples from 107 Italian women were analyzed by a highly typespecific multiplex genotyping assay for the presence of DNA from 119 different HPVs. Tissues were further analyzed for HPV RNA and for upregulation of the cellular protein p16 $6^{\text {INK4a }}$.

Results: The rate of mucosal HPV-related tumors defined by viral DNA and RNA positivity was low (7.8\%). HPV16 was the most prevalent, followed by 53, 56, and 58. Only five (4.9\%) p16 $6^{\text {INK4a }}$-positive tumors were also positive for both viral DNA and RNA. One (14.3\%) metastatic lymph node sample was positive for all three markers. DNA of cutaneous HPVs was detected in only two VSCCs, i.e. genus beta types 5 and 110.

Conclusion: A small proportion of Italian VSCCs is putatively HPV-related, i.e. positive for both viral DNA and RNA of the same type, thus reinforcing the importance of HPV vaccination. Moreover, this study suggests that a direct role of HPV from genus beta and gamma in vulvar carcinogenesis is unlikely.
\end{abstract}

Keywords: Cancer, Human papillomavirus, Lymph node metastatic tissues, Vulvar squamous cell carcinoma, Multiple markers of viral infections

\section{Introduction}

Vulvar squamous cell carcinoma (VSCC) is a rare tumor of the female genital tract, accounting for about $5 \%$ of all gynecological malignancies [1, 2]. In North America, the incidence of VSCC has increased by $0.6 \%$ annually in the past decade $[1,3,4]$. Moreover, tumor nodal recurrence is typically fatal [1]. The primary treatment approach for VSCC is surgery, complemented in selected cases by

\footnotetext{
* Correspondence: gheitt@iarc.fr; icb@iarc.fr

${ }^{2}$ International Agency for Research on Cancer, Lyon, France

Full list of author information is available at the end of the article
}

chemotherapy/radiotherapy [5], with negative psychosexual consequences $[1,6]$. VSCC includes two distinct types, with apparently different etiology: (i) VSCC associated with infection with mucosal high-risk (HR) human papillomaviruses (HPVs), and (ii) HPV-independent VSCC [7, 8]. HPV-related VSCC is more common in younger women and is always preceded by a pre-malignant lesion, i.e. vulvar high-grade squamous intraepithelial lesion (VHSIL) $[9,10]$. HPV-independent VSCC occurs mainly in older women $[1,11]$ and arises from a chronic inflammatory dermatosis, referred to as lichen sclerosus [12, 13], 
that can evolve into differentiated vulvar intraepithelial neoplasia (VIN), a precursor lesion of VSCC [14].

Based on a pooled prevalence rate of HPV DNA, 34\% of vulvar cancers have been reported to be attributable to HPV [15].

Although detection of HR-HPV DNA is a valid testing approach for the identification of pre-malignant and malignant cervical lesions, its use for other anatomical sites, including the vulva, is insufficient proof for viral causality and can lead to misclassification of the lesion [16, 17]. Therefore, the use of additional markers for active HR-HPV infections, such as overexpression of the human cyclin-dependent kinase-4 inhibitor $\mathrm{p} 16^{\mathrm{INK} 4 \mathrm{a}}$ (p16) or/and detection of viral RNA, may enable more precise estimation of the proportion of VSCC that may be attributable to HPV, as previously shown in head and neck cancer [16].

As recently suggested, a useful protocol for the identification of HPV-related VSCC is the simultaneous detection of HPV DNA and RNA [16, 17].

The evaluation of $\mathrm{p} 16$ protein expression by immunohistochemistry (IHC) enables discrimination between HPV-independent and HPV-related cancers at anatomical sites outside the cervix, including the vulva [17-21]. However, because there are a limited number of studies evaluating p16 expression in VSCC, the actual reliability of p16 protein expression as a single marker of oncogenic HPV infection for this tumor entity is not entirely known [17, 18, 22, 23]. Detection of both HPV DNA and p16 overexpression to classify the two different VSCC subtypes has also been proposed, but for VSCC this algorithm has not yet been fully validated [17, 18, 21]. However, the detection of viral transcripts as a marker of biological HPV activity in the lesion tissue, in addition to HPV DNA and p16 overexpression, may significantly improve the classification of truly HPVpositive VSCC.

A multicenter study using HPV DNA and $\mathrm{p} 16$ positivity as markers has shown that approximately $25 \%$ of vulvar cancers worldwide may be associated with HPV [18]. This study, which included tumor specimens collected from cancer cases in 39 countries on five continents, highlighted some variability in HPV positivity in VSCC in the different geographical regions. However, some geographical variations in HPV-positive VSCC may be due simply to the analysis of a relatively low number of specimens in specific countries. Thus, additional studies are required in individual countries, where only limited information on the association between HR-HPV and VSCC is available.

Regarding HR-HPV-negative VSCC, the involvement of other infectious agents, including the cutaneous genus beta and gamma HPV types, has been poorly investigated. Studies have reported the presence of these HPV types in the anogenital tract [24, 25]. In addition, several investigations have highlighted the transforming properties of genus beta and gamma HPV types in various experimental models [26-28].

In this study, we aimed to determine the HPVattributable proportion of VSCC by analyzing HPV DNA and RNA status, and by determining p16 expression level, in a large retrospective cohort of VSCC cases from Italy. In addition, we examined the possible role of genus beta and/or gamma HPV types in VSCC.

\section{Materials and methods \\ Sample collection}

The Ethics Committee of the Hospital of Turin approved this study to be in compliance with the Declaration of Helsinki (reference number 1005). All patients had signed informed consent at the time of hospital admission. The inclusion criteria were: invasive vulvar carcinoma (i.e. an invasive depth $>1 \mathrm{~mm}$ ), squamous cell histological type, and no prior surgical treatment for vulvar cancer or any other malignancy (apart from biopsy). The exclusion criteria were: primary site other than vulva, recurrent tumors, HIV- or hepatitis $\mathrm{C}$ virus (HCV)-positive patients, and non-consenting patients.

Formalin-fixed, paraffin-embedded (FFPE) VSCC samples obtained from 107 women (mean [ \pm standard deviation (SD)] age, 73 [11.8] years) collected during 2013-2016 were retrieved from the archive of the Department of Obstetrics and Gynecology, University of Turin, Sant'Anna Hospital, Turin, Italy. According to the International Federation of Gynecology and Obstetrics (FIGO) classification of vulvar cancer [29], the VSCCs were in the following stages: IB (54.2\%); II (0.9\%); IIIA (19.6\%); IIIB (11.2\%); IIIC (4.7\%); and IVA (9.3\%). The mean tumor diameter was $29 \mathrm{~mm}$ (SD, 15.8 $\mathrm{mm}$ ), and $42.1,45.8$, and $12.1 \%$ of tumors showed depth of invasion of $<5 \mathrm{~mm}, 5-12 \mathrm{~mm}$, and $>12 \mathrm{~mm}$, respectively. Archived FFPE metastatic lymph node samples (MTS) were also available from 8 women with VSCC tissue (mean $[ \pm$ SD] age, 69 [16.5] years).

\section{Preparation of paraffin sections and tumor evaluation}

Ten sections of $10 \mu \mathrm{m}$ from each FFPE tissue block were processed at the Department of Pathology, University of Turin, Italy. Sections S1 and S10 were used for hematoxylin and eosin histology, and S2 and S9 were used for p16 IHC. In addition, S3-S5 and S6-S8 were collected for DNA and RNA extraction, respectively. To avoid cross-contamination between different samples, each time a new case was sectioned, the microtome was extensively washed with DNA Away (Dutscher, Brumath, France) and a new microtome blade was used. Empty paraffin blocks were cut after every 10 cancer specimens and blindly analyzed. Tumor size/status was documented by routine pathologic evaluation, in 
accordance with the World Health Organization (WHO) classification [30].

\section{Nucleic acid extraction}

Total DNA was prepared by incubating overnight at $37^{\circ} \mathrm{C}$ three internal FFPE sections (S3-S5) from each VSCC/ MTS tissue in $250 \mu \mathrm{l}$ of digestion buffer $(10 \mathrm{mM}$ Tris/HCl at $\mathrm{pH} 7.4,0.5 \mathrm{mg} / \mathrm{ml}$ proteinase $\mathrm{K}$, and $0.4 \%$ Tween 20 ). Then, to inactivate the proteinase $\mathrm{K}$ and to separate paraffin from the aqueous phase, samples were incubated at $95^{\circ} \mathrm{C}$ for $10 \mathrm{~min}$, centrifuged, and chilled on ice [31]. The aqueous phase was transferred to a new tube.

Total RNA was prepared from tissue sections S6-S8 using the PureLink FFPE Total RNA Isolation Kit (Invitrogen, Carlsbad, CA, USA). DNase I (RNase-Free DNase Set, Qiagen, Hilden, Germany) treatment was carried out on the RNA purifying columns during sample processing as previously described [32]. Extracted RNA was eluted in $50 \mu \mathrm{l}$ of RNase-free water and stored at $-80^{\circ} \mathrm{C}$ until use.

\section{HPV DNA detection and genotyping}

HPV DNA was detected by E7 type-specific multiplex genotyping (E7-MPG), which combines multiplex polymerase chain reaction (PCR) and hybridization to typespecific oligonucleotide probes on fluorescent beads (Luminex Corp., Austin, TX, USA) [33, 34]. E7-MPG uses HPV type-specific primers targeting the E7 region of 12 HR-HPVs (HPV16, 18, 31, 33, 35, 39, 45, 51, 52, $56,58,59), 7$ possible/probable HR (pHR)-HPVs (HPV26, 53, 66, 68, 70, 73, 82), and two low-risk (LR) HPVs (HPV6 and 11). Forty-six genus beta HPVs (HPV5, 8, 9, 12, 14, 15, 17, 19, 20, 21, 22, 23, 24, 25, 36, $37,38,47,49,75,76,80,92,93,96,98,99,100,104$, $105,107,110,111,113,115,118,120,122,124,143$, $145,150,151,152,159,174)$ and 52 genus gamma HPVs (HPV4, 48, 50, 60, 65, 88, 95, 101, 103, 108, 109, 112, $116,119,121,123,126,127,128,129,130,131,132$, $133,134,148,149,156,161,162,163,164,165,166$, $167,168,169,170,171,172,173,175,178,179,180$, 184, 197, 199, 200, 201, 202, SD2) [35-41] were detected using the same methodology.

The sensitivity has been evaluated using serial dilutions of DNA from HPV types. This multiplex PCR protocol is highly sensitive, with the ability to detect only 10 copies of the viral genome $[34,40]$.

\section{HPV mRNA analysis}

All HPV DNA-positive VSCC/MTS tissues, including HPV16 and non-HPV16 DNA-positive samples, and a group of 10 randomly selected HPV DNA-negative tissues were analyzed for HPV16 E6*I mRNA and, as a control for tissue and RNA quality, for human UbC mRNA. Tissues that were DNA-positive for HR- and pHR-HPV types other than HPV16 were also analyzed for E6*I mRNA of the specific HR- and pHR-HPV types(s) detected. In addition, tissues that were DNA-positive for LR-HPV6 or 11 were analyzed for the presence of unspliced E6 mRNA of HPV6 and 11, respectively. RNA detection from FFPE sections was performed as previously described [32]. Briefly, $1 \mu \mathrm{l}$ of extracted RNA was subjected to a one-step reverse transcription PCR protocol with the QuantiTect Virus Kit (Qiagen, Hilden, Germany) using HPV typespecific primers to amplify 65-75 bp cDNA sequences across the E6*I splice sites [32]. The biotinylated strands of the amplicons were detected by hybridization with type- and splice site-specific oligonucleotide probes coupled to fluorescence-labelled Luminex beads (Luminex Corp., Austin, TX, USA). The E6*I mRNA assays are available for $20 \mathrm{HR}$ - or pHR-HPV types for which existence of splice sites was demonstrated [32]. For detection of unspliced LR-HPV6 and 11 mRNA, primers designed to amplify a $77 \mathrm{bp}$ amplicon of the full-length HPV6 or 11 E6 gene, and an oligonucleotide probe for detection of full-length HPV11 E6, were applied.

Samples that were negative in duplicate assays for HPV E6*I or E6 and for UbC mRNA were considered RNA-invalid.

\section{p16 immunohistochemistry}

Expression of p16 was evaluated manually by IHC in FFPE sections using the CINtec p16 Histology Kit (Roche mtm laboratories AG, Mannheim, Germany) according to the manufacturer's instructions and as previously described [42]. Expression of p16 was evaluated by IHC in all VSCC and MTS cases. Continuous, diffuse nuclear and cytoplasmic staining in $70 \%$ or more of the tumor cells was considered p16-positive, and focal staining or no staining was considered p16-negative. All slides were evaluated three times by three different evaluators (SSP, RW, RR), who were blinded to the clinical and epidemiological data. The final classification of the staining was based on the majority consensus.

\section{Results}

\section{HPV infection markers in VSCCs}

Of 107 VSCC and 8 MTS cases initially selected, five VSCC cases and one MTS case were excluded due to invalid RNA $(n=3)$ and p16 $(n=2)$ data, or to the absence of cancer tissue in the block $(n=1)$. Thus, a total of 102 VSCC and 7 MTS tissues were included in the analysis. The 102 VSCC cases had a mean age of 70 years (SD, 12.8 years); FIGO stages were IB (52.9\%), II (1\%), IIIA (20.6\%), IIIB (10.8\%), IIIC (4.9\%), and IVA (9.8\%). Mean tumor diameter was $30 \mathrm{~mm}(\mathrm{SD}, 15.7 \mathrm{~mm})$ and mean depth of stromal invasion $8 \mathrm{~mm}(\mathrm{SD}, 6.3 \mathrm{~mm})$, with 40.2 , 47.1 and $12.7 \%$ of tumors showing depth of invasion of $<$ $5 \mathrm{~mm}, 5-12 \mathrm{~mm}$, and $>12 \mathrm{~mm}$, respectively. Furthermore, 
MTS selected from 7 cases were analyzed (mean $[ \pm \mathrm{SD}]$ age, 73.9 [13.5] years).

Table 1 and Supplementary Table S1 show the HPV DNA, RNA, and p16 detection in VSCC and MTS cases. Mucosal HPV DNA was detected in 17 of 102 (16.7\%) VSCCs and all 7 MTS cases (100\%). HPV16 was the most prevalent type; it was present in 10 of the 17 HPV DNApositive VSCCs $(58.8 \%)$, followed by HPV6 $(2 / 17,11.8 \%)$, HPV18 (1/17, 5.9\%), HPV53 (1/17, 5.9\%), HPV56 (1/17, 5.9\%), HPV58 (1/17, 5.9\%), and HPV82 (1/17, 5.9\%). Only one multiple infection was detected, containing HPV16, 18, and 56. All MTS cases were positive for mucosal HPV DNA. Five MTS cases contained a single HPV type, i.e. HPV16 $(n=1)$, HPV6 $(n=3)$, and HPV56 $(n=1)$. Multiple HPV infections were detected in two MTS cases; both were positive for HPV6 and HPV16 (Table 1). Matched VSCC and MTS cases of three women were positive for the same HPV DNA, i.e. HPV6 $(n=2)$ and HPV16 $(n=1)$. There was no concordance for the HPV types in the remaining MTS cases $(n=4)$ and the corresponding VSCCs (Supplementary Table S1).

To evaluate the etiological role of the mucosal HPV detected, all 17 HPV DNA-positive VSCC and all 7 MTS cases were analyzed for the presence of HR- and pHRHPV E6*I and unspliced E6 for LR-HPV (Table 1). All 24 HPV DNA-positive VSCC and MTS cases were ubC mRNA-positive. Considering both HPV DNA and RNA positivity, the percentage of HPV-related VSCCs was $7.8 \%(8 / 102)$, i.e. HPV16 $(n=6)$, HPV53 $(n=1)$, HPV56 $(n=1)$, and HPV58 $(n=1)$. One VSCC case simultaneously tested positive for HPV DNA and RNA from HPV16 and HPV56. Of the 7 mucosal HPV DNApositive MTS cases, only one (14.3\%) had E6*I mRNA of the same type (HPV16). None of the HPV6 DNApositive cases tested positive for full-length HPV6 E6 mRNA.

Overexpression of the cell-cycle inhibitor p16 is a well-validated surrogate marker of HPV transformation in the cervix [43]. We determined the p16 IHC positivity in all 102 VSCC and 7 MTS cases (Fig. 1). Eleven VSCC cases were positive for p16 (11/102, 10.8\%). Of these, five were also HPV DNA- and RNA-positive (Table 1). Thus, when all three markers were considered, the percentage of HPV-related VSCC cases dropped from 7.8 to $4.9 \%(5 / 102)$ (Table 1). The remaining p16-positive cases $(n=6)$ were HPV DNA-positive and HPV RNA-negative $(n=2)$ or HPV DNA-negative and HPV RNA-negative $(n=2)$, or were not tested for HPV DNA and RNA $(n=$ $2)$. Only one MTS case showed p16 overexpression (1/7, 14.3\%), and was also positive for HPV16 DNA and RNA. The corresponding VSCC from the same case was also positive for all three markers.

The presence of DNA of cutaneous beta and gamma HPV in cytological samples of the genital tract has been

Table 1 HPV DNA, RNA, and p16 positivity in 102 VSCC and 7 MTS cases

\begin{tabular}{|c|c|c|c|}
\hline & & $\operatorname{VSCC}(N=102)$ & MTS $(N=7)$ \\
\hline HPV type & Marker positivity & $\begin{array}{l}\text { Positive } \\
n(\%)\end{array}$ & $\begin{array}{l}\text { Positive } \\
n(\%)\end{array}$ \\
\hline \multirow[t]{3}{*}{ Any HPV } & DNA & $17(16.7)$ & $7(100.0)$ \\
\hline & DNA and $R N A^{a}$ & $8(7.8)$ & $1(14.3)$ \\
\hline & DNA, RNA, and $\mathrm{p} 16^{\mathrm{a}}$ & $5(4.9)$ & $1(14.3)$ \\
\hline \multirow[t]{3}{*}{ HPV16 single infection } & DNA & $9(8.8)$ & $1(14.3)$ \\
\hline & DNA and RNA & $5(4.9)$ & $0(0.0)$ \\
\hline & DNA, RNA, and p16 & $4(3.9)$ & $0(0.0)$ \\
\hline \multirow[t]{3}{*}{ Mucosal HPV other than HPV16 single infections } & DNA & $7(6.9)^{b}$ & $4(57.1)^{d}$ \\
\hline & DNA and RNA & $2(2.0)^{c}$ & $0(0.0)$ \\
\hline & DNA, RNA, and p16 & $0(0.0)$ & $0(0.0)$ \\
\hline \multirow[t]{3}{*}{ Multiple infections } & DNA & $1(1.0)^{\mathrm{e}}$ & $2(28.6)^{9}$ \\
\hline & DNA and RNA & $1(1.0)^{f}$ & $1(14.3)^{\mathrm{h}}$ \\
\hline & DNA, RNA, and p16 & $1(1.0)$ & $1(14.3)$ \\
\hline
\end{tabular}

HPV Human papillomavirus, MTS Metastatic lymph node samples, VSCC Vulvar squamous cell carcinoma

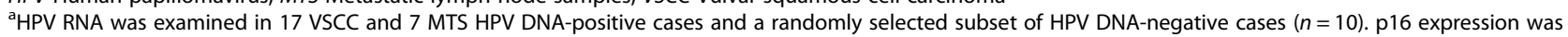
examined in all VSCC $(n=102)$ and MTS $(n=7)$ cases

bSingle infections: HPV6 $(n=2), \operatorname{HPV} 18(n=1), \operatorname{HPV} 53(n=1), \operatorname{HPV} 56(n=1), \operatorname{HPV} 58(n=1), \operatorname{HPV} 82(n=1)$

'Single infections: HPV53 $(n=1), \operatorname{HPV} 58(n=1)$

${ }^{\mathrm{d}}$ Single infections: HPV6 $(n=3)$, HPV56 $(n=1)$

${ }^{\mathrm{e} C o i n f e c t i o n: ~ H P V 16, ~ H P V 18, ~ a n d ~ H P V 56 ~}(n=1)$

${ }^{f}$ Coinfection: HPV16 and HPV56 $(n=1)$

9Coinfection: HPV6 and HPV16 $(n=2)$

hingle infection: HPV16 $(n=1)$ 


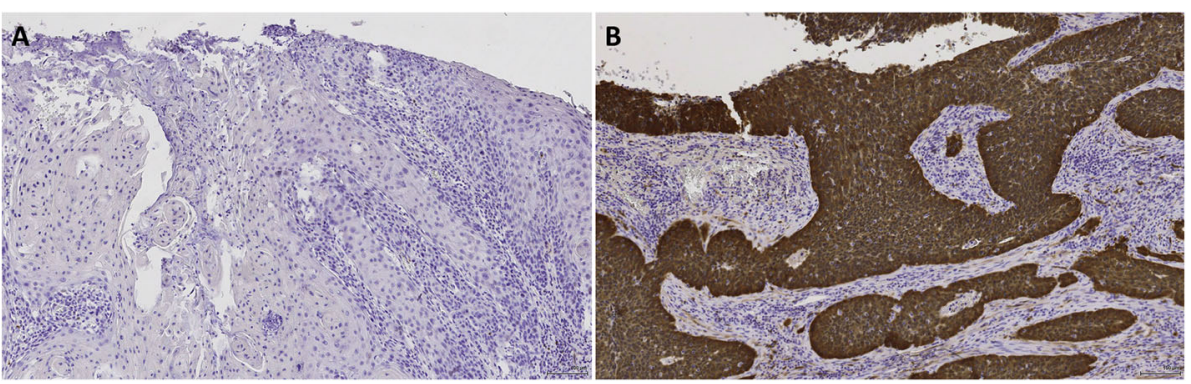

Fig. 1 p16 $6^{\text {ink4a }}$ immunohistochemistry staining. Negative p $16^{\text {ink4a }}$ staining $(\mathbf{a})$, and diffuse nuclear and cytoplasmic p16 $6^{\text {ink4a }}$ staining (b) in VSCC cases. Magnification $\times 10$

reported [24, 37, 44]. We also determined the presence of DNA of 46 genus beta and 52 genus gamma HPV types in all VSCC and MTS cases. Only two VSCC cases were positive for beta HPV types (i.e. HPV5 and HPV110), and no gamma HPV types were detected in the VSCC and MTS cases analyzed.

\section{Discussion}

Mucosal HR-HPV types have been clearly associated with the development of a small subset of VSCC. However, the contribution of the viral infectious agents appears to vary in different geographical regions [15]. In particular, limited information is available for the contribution of HR-HPV to VSCC development in Italy. In this study, we analyzed a large number of VSCCs collected in a hospital in northern Italy during 2013-2016.

In the first step, we investigated the presence of HPV DNA in VSCCs by using a sensitive HPV genotyping approach covering all oncogenic and probably/possibly oncogenic HPV types. The prevalence of HPV DNApositive cases was observed to be nearly $17 \%$. Previous studies on VSCC reported HPV DNA frequencies ranging from 29 to $45 \%$ [17, 18, 21, 45, 46]. However, the overall results indicate that HPV could have a role in the development of a proportion of VSCC cases. In agreement with a previous study [17], we observed HPV16 to be the most common HR-HPV type detected in VSCC. In addition, viral DNA from HPV18, 53, 56, 58, and 82 was also detected, with low frequency. The LR-HPV type 6 was found to be the second most common viral type in this study, suggesting that it may be involved, together with other factors, in VSCC onset or progression [17, 46]. Recently, Faber et al. (2017) reported a prevalence of $6.8 \%(19 / 277)$ for HPV6 DNA as a single infection in VIN, and 1.1\% (6/527) in VSCC [47].

Because HPV transcriptional activity may reflect its oncogenic activity, we applied a HPV-type-specific E6*I mRNA detection method, established for $20 \mathrm{HR}$ - or pHR-HPV types and validated for use in FFPE tissues, to evaluate the presence of HPV RNA in HPV DNApositive VSCCs. We observed viral RNA in $47.1 \%(8 / 17)$ of HPV DNA-positive VSCC cases, with HPV16 RNA showing the highest prevalence. Eight of 102 VSCC cases $(7.8 \%)$ were likely to be HPV-driven, i.e. positive for both HPV DNA and RNA. None of the HPV6 DNApositive samples tested positive for HPV RNA. The upregulation of p16 has been suggested as a surrogate marker for oncogenic HR-HPV infections, and p16 IHC has frequently been used not only to determine and/or confirm positivity for HPV in various tumors but also to define HPV-related tumors [19]. Therefore, p16 expression has also been studied in VSCC before [17, 22, 48, 49]. In the present study, this cellular marker was overexpressed in approximately 50\% of HR-HPV DNApositive VSCC cases (7/15). Other series of VSCC studies previously showed $70-80 \%$ of HPV DNA-positive VSCC cases expressing p16 $[17,46]$. However, in our study, p16 overexpression was observed in the majority $(5 / 8,62.5 \%)$ of HR-HPV DNA- and RNA-positive VSCCs. A lower p16 positivity rate in HR-HPV DNAnegative VSCCs $(4 / 85,4.7 \%)$ and in HR-HPV DNApositive and HPV RNA-negative VSCCs $(2 / 7,28.6 \%)$ was also detected. Overexpression of p16 in HPV DNAnegative VSCCs may be a consequence of either a mutation of $C D K N 2 A$, the gene coding for p16 [50], or the inactivation of the retinoblastoma protein $\mathrm{pRb}$ (e.g. by mutation), which then leads to upregulation of p16 [51].

Previous reports showed higher concordance between the HR-HPV transcript expression and p16 overexpression, ranging from 83 to $90 \%[17,21,49]$. The causes of this discrepancy between our results and those of previous published studies are unknown.

In this study, we were also able to retrieve MTSs for a small number of patients with VSCC. Only one case showed concordance in HPV DNA/RNA positivity and p16 expression between VSCC and MTS.

The investigation of the presence of HR-HPV E6 mRNA instead of analyzing E6 oncoprotein, which may be more informative on the oncogenic implications of HR-HPVs in VSCC development, may be considered a limitation of this study. However, we focused our attention on evaluating the expression of the p16 protein, 
which is considered a surrogate marker for all transforming HR-HPV infections and represents a single target molecule, different from the E6 proteins with typespecific polypeptide sequence variability.

Finally, although independent studies have reported that cutaneous beta and gamma HPV types can be detected in the genital tract, our study does not provide evidence for their involvement in the development of VSCC.

\section{Conclusion}

We characterized the HPV-independent and HPVrelated VSCCs in a cohort of more than 100 VSCC cases from Italy. We identified as putative HPV-related tumors a small proportion of VSCC cases that tested positive for both HPV DNA and RNA. Our results support the causative role of HPV in vulvar carcinogenesis in a distinct subset of cases and highlight the prevalence of HPV16, thus reinforcing the importance of HPV vaccination programs.

\section{Supplementary information}

Supplementary information accompanies this paper at https://doi.org/10. 1186/s13027-020-00286-8.

Additional file 1: Table S1. HPV DNA, HPV RNA and p16 status in 102

VSCC and 7 MTS individual cases.

\section{Abbrevations}

VSCC: Vulvar squamous cell carcinoma; VHSIL: Vulvar high-grade squamous intraepithelial lesion; HPV: Human papillomavirus; HR: High-risk; FFPE: Formalin-fixed, paraffin-embedded; IHC: Immunohistochemistry; WHO: World Health Organization

\section{Acknowledgements}

We are grateful to to Ms. Nicole Suty for her help with preparation of this manuscript.

\section{Disclaimer}

Where authors are identified as personnel of the International Agency for Research on Cancer/World Health Organization, the authors alone are responsible for the views expressed in this article and they do not necessarily represent the decisions, policy, or views of the International Agency for Research on Cancer/World Health Organization.

\section{Authors' contribution}

Conceptualization: MPr, NG, CB, MT, TG; Investigation: MPr, JCR, MT, TG; Resources: MPr, LM, NG, NG, CB; Supervision: MPr, MPa, MT, TG; Writing - original draft: JCR, MT, TG; Formal analysis: JCR, DH, SSP, RW, RR, TG; Funding acquisition: JCR, MT; Validation: DH, SSP, RW, RR, MPa, MT, TG; Data curation: DH, SSP, TG; Methodology: DH, SMC, CC, RR, MPa, MT, TG; Writing - review \& editing: MPr, JCR, NG, RR, MPa, MT, TG. The author(s) read and approved the final manuscript.

\section{Funding}

The study was partially supported by the HPV-AHEAD grant (FP7-HEALTH2011-282562) from the European Commission to MT and by a fellowship from the Fondazione Guido Berlucchi, Milan, Italy, to JCR.

\section{Ethics approval and consent to participate}

The Ethics Committee of the Hospital of Turin approved this study to be in compliance with the Declaration of Helsinki (reference number 1005). All patients had signed informed consent at the time of hospital admission.

\section{Consent for publication}

Not applicable.

\section{Competing interests}

R. Ridder is an employee of Roche. All other authors report no conflict of interest.

\section{Author details}

${ }^{1}$ Department of Surgical Sciences, University of Turin, Turin, Italy. ${ }^{2}$ International Agency for Research on Cancer, Lyon, France. ${ }^{3}$ Department of Morphology, Surgery and Experimental Medicine; Section of Pathology, Oncology and Experimental Biology; Laboratories of Cell Biology and Molecular Genetics, University of Ferrara, Ferrara, Italy. ${ }^{4}$ Infections and Cancer Epidemiology, Infections and Cancer Program, German Cancer Research Center (DKFZ), Heidelberg, Germany. ${ }^{5}$ Department of Oncology, Città della Salute e della Scienza, University of Turin, Turin, Italy. ${ }^{6}$ Roche mtm laboratories, Mannheim, Germany. 7 Ventana Medical Systems Inc., Tucson, AZ, USA.

Received: 15 January 2020 Accepted: 23 March 2020

Published online: 01 April 2020

\section{References}

1. Clancy AA, Spaans JN, Weberpals JI. The forgotten woman's cancer: vulvar squamous cell carcinoma (VSCC) and a targeted approach to therapy. Ann Oncol. 2016;27(9):1696-705. https://doi.org/10.1093/annonc/mdw242.

2. Hacker NF, Eifel PJ, van der Velden J. Cancer of the vulva. Int J Gynaecol Obstet. 2015;131(Suppl 2):S76-83. https://doi.org/10.1016/j.ijgo.2015.06.002.

3. Akhtar-Danesh $\mathrm{N}$, Elit L, Lytwyn A. Trends in incidence and survival of women with invasive vulvar cancer in the United States and Canada: a population-based study. Gynecol Oncol. 2014;134(2):314-8. https://doi.org/ 10.1016/j.ygyno.2014.05.014.

4. Bodelon C, Madeleine MM, Voigt LF, Weiss NS. Is the incidence of invasive vulvar cancer increasing in the United States? Cancer Causes Control. 2009; 20(9):1779-82. https://doi.org/10.1007/s10552-009-9418-8.

5. Oonk MHM, Planchamp F, Baldwin P, Bidzinski M, Brännström M, Landoni F, Mahner S, Mahantshetty U, Mirza M, Petersen C, Querleu D, Regauer S, Rob $\mathrm{L}$, Rouzier R, Ulrikh E, van der Velden J, Vergote I, Woelber L, van der Zee AGJ. European Society of Gynaecological Oncology Guidelines for the management of patients with vulvar Cancer. Int J Gynecol Cancer. 2017; 27(4):832-7. https://doi.org/10.1097/IGC.0000000000000975.

6. Forner DM, Dakhil R, Lampe B. Quality of life and sexual function after surgery in early stage vulvar cancer. Eur J Surg Oncol (EJSO). 2015;41(1):405. https://doi.org/10.1016/j.ejso.2014.10.050.

7. del Pino $M$, Rodriguez-Carunchio $L$, Ordi J. Pathways of vulvar intraepithelial neoplasia and squamous cell carcinoma. Histopathology. 2013;62(1):161-75. https://doi.org/10.1111/his.12034.

8. Swarts DRA, Voorham QJM, van Splunter AP, Wilting SM, Sie D, Pronk D, van Beurden M, Heideman DAM, Snijders PJF, Meijer CJLM, Steenbergen RDM, Bleeker MCG. Molecular heterogeneity in human papillomavirus-dependent and -independent vulvar carcinogenesis. Cancer Med. 2018;7(9):4542-53. https://doi.org/10.1002/cam4.1633.

9. Bornstein J, Bogliatto F, Haefner HK, Stockdale CK, Preti M, Bohl TG, Reutter J. The 2015 International Society for the Study of Vulvovaginal Disease (ISSVD) Terminology of Vulvar Squamous Intraepithelial Lesions. Obstet Gynecol. 2016;127(2):264-8. https://doi.org/10.1097/AOG.0000000000001285.

10. van der Avoort IA, Shirango H, Hoevenaars BM, Grefte JM, de Hullu JA, de Wilde PC, Bulten J, Melchers WJ, Massuger LF. Vulvar squamous cell carcinoma is a multifactorial disease following two separate and independent pathways. Int J Gynecol Pathol. 2006;25(1):22-9.

11. Roma AA, Hart WR. Progression of simplex (differentiated) vulvar intraepithelial Neoplasia to invasive squamous cell carcinoma: a prospective case study confirming its precursor role in the pathogenesis of vulvar Cancer. Int J Gynecol Pathol. 2007;26(3):248-53. https://doi.org/10.1097/01. pgp.0000236944.36593.d0. 
12. Cohen PA, Anderson L, Eva L, Scurry J. Clinical and molecular classification of vulvar squamous pre-cancers. Int J Gynecol Cancer. 2019;29(4):821-8. https://doi.org/10.1136/ijgc-2018-000135.

13. Rotondo JC, Borghi A, Selvatici R, Mazzoni E, Bononi I, Corazza M, Kussini J, Montinari E, Gafà R, Tognon M, Martini F. Association of Retinoic Acid Receptor $\beta$ gene with onset and progression of lichen Sclerosus-associated vulvar squamous cell carcinoma. JAMA Dermatol. 2018;154(7):819. https:// doi.org/10.1001/jamadermatol.2018.1373.

14. Rotondo JC, Borghi A, Selvatici R, Magri E, Bianchini E, Montinari E, Corazza M, Virgili A, Tognon M, Martini F. Hypermethylation-induced inactivation of the IRF6 gene as a possible early event in progression of vulvar squamous cell carcinoma associated with lichen Sclerosus. JAMA Dermatol. 2016; 152(8):928. https://doi.org/10.1001/jamadermatol.2016.1336.

15. Zhang J, Zhang Y, Zhang Z. Prevalence of human papillomavirus and its prognostic value in vulvar cancer: a systematic review and meta-analysis. PLoS One. 2018;13(9):e0204162. https://doi.org/10.1371/journal.pone. 0204162.

16. Castellsague X, Alemany L, Quer M, Halec G, Quiros B, Tous S, Clavero O, Alos L, Biegner T, Szafarowski T, Alejo M, Holzinger D, Cadena E, Claros E, Hall G, Laco J, Poljak M, Benevolo M, Kasamatsu E, Mehanna H, Ndiaye C, Guimera N, Lloveras B, Leon X, Ruiz-Cabezas JC, AlvaradoCabrero I, Kang CS, Oh JK, Garcia-Rojo M, Iljazovic E, OF A, Duarte F, Nessa A, Tinoco L, Duran-Padilla MA, Pirog EC, Viarheichyk $H$, Morales H, Costes V, Felix A, Germar MJ, Mena M, Ruacan A, Jain A, Mehrotra R, Goodman MT, Lombardi LE, Ferrera A, Malami S, Albanesi El, Dabed P, Molina C, Lopez-Revilla R, Mandys V, Gonzalez ME, Velasco J, Bravo IG, Quint W, Pawlita M, Munoz N, de Sanjose S, Xavier Bosch F, Head ICOIHi, Neck Cancer Study G. HPV Involvement in Head and Neck Cancers: Comprehensive Assessment of Biomarkers in 3680 Patients. J Natl Cancer Inst. 2016;108(6):djv403. https://doi.org/10.1093/jnci/djv403.

17. Halec G, Alemany L, Quiros B, Clavero O, Hofler D, Alejo M, Quint W, Pawlita M, Bosch FX, de Sanjose S. Biological relevance of human papillomaviruses in vulvar cancer. Mod Pathol. 2017;30(4):549-62. https://doi.org/10.1038/ modpathol.2016.197

18. de Sanjose $S$, Alemany L, Ordi J, Tous S, Alejo M, Bigby SM, Joura EA, Maldonado P, Laco J, Bravo IG, Vidal A, Guimera N, Cross P, Wain GV, Petry KU, Mariani L, Bergeron C, Mandys V, Sica AR, Felix A, Usubutun A, Seoud M, Hernandez-Suarez G, Nowakowski AM, Wilson G, Dalstein V, Hampl M, Kasamatsu ES, Lombardi LE, Tinoco L, Alvarado-Cabrero I, Perrotta M, Bhatla N, Agorastos T, Lynch CF, Goodman MT, Shin HR,

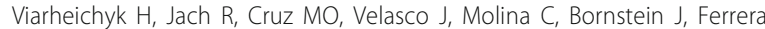
A, Domingo EJ, Chou CY, Banjo AF, Castellsague X, Pawlita M, Lloveras B, Quint WG, Munoz N, Bosch FX, group HVs. Worldwide human papillomavirus genotype attribution in over 2000 cases of intraepithelial and invasive lesions of the vulva. Eur J Cancer (Oxford, England : 1990). 2013;49(16):3450-61. https://doi.org/10.1016/j.ejca.2013.06.033.

19. El-Naggar AK, Westra WH. p16 expression as a surrogate marker for HPVrelated oropharyngeal carcinoma: a guide for interpretative relevance and consistency. Head Neck. 2012;34(4):459-61. https://doi.org/10.1002/hed.21974.

20. Hoevenaars BM, van der Avoort IAM, de Wilde PCM, Massuger LFAG, Melchers WJG, de Hullu JA, Bulten J. A panel of p16 INK4A , MIB1 and p53 proteins can distinguish between the 2 pathways leading to vulvar squamous cell carcinoma. Int J Cancer. 2008;123(12):2767-73. https://doi. org/10.1002/ijc.23857.

21. Rakislova N, Clavero O, Alemany L, Saco A, Quirós B, Lloveras B, Alejo M, Pawlita M, Quint W, del Pino M, de Sanjose S, Ordi J, group oboVs. "Histological characteristics of HPV-associated and -independent squamous cell carcinomas of the vulva: a study of 1,594 cases": HPV in vulvar cancer. Int J Cancer. 2017;141(12):2517-27. https://doi.org/10.1002/ijc.31006.

22. Cheng AS, Karnezis AN, Jordan S, Singh N, McAlpine JN, Gilks CB. p16 Immunostaining Allows for Accurate Subclassification of Vulvar Squamous Cell Carcinoma Into HPV-Associated and HPV-Independent Cases. Int J Gynecol Pathol. 2016;35(4):385-93. https://doi.org/10.1097/PGP. 0000000000000263.

23. Santos M, Montagut C, Mellado B, Garcia A, Ramon y Cajal S, Cardesa A, Puig-Tintore LM, Ordi J. Immunohistochemical staining for p16 and p53 in premalignant and malignant epithelial lesions of the vulva. Int J Gynecol Pathol. 2004;23(3):206-14.

24. Chen Z, Schiffman M, Herrero R, Desalle R, Burk RD. Human papillomavirus (HPV) types 101 and 103 isolated from cervicovaginal cells lack an E6 open reading frame (ORF) and are related to gamma-papillomaviruses. Virology. 2007;360(2):447-53. https://doi.org/10.1016/j.virol.2006.10.022.

25. Rollison DE, Schell MJ, Fenske NA, Cherpelis B, Messina JL, Giuliano AR, Epling-Burnette PK, Hampras SS, Amorrortu RP, Balliu J, Vijayan L, Naqvi SMH, Zhao Y, Parab K, McKay-Chopin S, Gheit T, Tommasino M. Cutaneous viral infections across 2 anatomic sites among a cohort of patients undergoing skin Cancer screening. J Infect Dis. 2019;219(5):711-22. https:// doi.org/10.1093/infdis/jiy577.

26. Nobre RJ, Herraez-Hernandez E, Fei JW, Langbein L, Kaden S, Grone HJ, de Villiers EM. E7 oncoprotein of novel human papillomavirus type 108 lacking the E6 gene induces dysplasia in organotypic keratinocyte cultures. J Virol. 2009;83(7):2907-16. https://doi.org/10.1128/JVI.02490-08.

27. Grace M, Munger K. Proteomic analysis of the gamma human papillomavirus type 197 E6 and E7 associated cellular proteins. Virology. 2017;500:71-81. https://doi.org/10.1016/j.virol.2016.10.010.

28. Tommasino M. The biology of beta human papillomaviruses. Virus Res. 2017;231:128-38. https://doi.org/10.1016/j.virusres.2016.11.013.

29. FIGO Committee on Gynecologic Oncology. FIGO staging for carcinoma of the vulva, cervix, and corpus uteri. Int J Gynaecol Obstet. 2014;125(2):97-8. https://doi.org/10.1016/j.ijgo.2014.02.003.

30. Crum CP, Herrington CS, McCluggage WG, Regauer S, Wilkinson EJ. Epithelial Tumours. In: Kurman RJ, Carcangiu ML, Herrington CS, Young RH, editors. WHO Classification of tumours of female reproductive Organs. 4th ed. Lyon: International Agency for Research on Cancer; 2014. p. 232-41.

31. Gheit T, Abedi-Ardekani B, Carreira C, Missad CG, Tommasino M, Torrente MC. Comprehensive analysis of HPV expression in laryngeal squamous cell carcinoma. J Med Virol. 2014;86(4):642-6. https://doi.org/10.1002/jmv.23866.

32. Halec G, Schmitt M, Dondog B, Sharkhuu E, Wentzensen N, Gheit T, Tommasino M, Kommoss F, Bosch FX, Franceschi S, Clifford G, Gissmann L, Pawlita M. Biological activity of probable/possible high-risk human papillomavirus types in cervical cancer. Int J Cancer. 2013;132(1):63-71. https://doi.org/10.1002/ijc.27605.

33. Gheit T, Landi S, Gemignani F, Snijders PJ, Vaccarella S, Franceschi S, Canzian $\mathrm{F}$, Tommasino M. Development of a sensitive and specific assay combining multiplex PCR and DNA microarray primer extension to detect high-risk mucosal human papillomavirus types. J Clin Microbiol. 2006:44(6):2025-31. https://doi.org/10.1128/JCM.02305-05.

34. Schmitt M, Dondog B, Waterboer T, Pawlita M, Tommasino M, Gheit T. Abundance of multiple high-risk human papillomavirus (HPV) infections found in cervical cells analyzed by use of an ultrasensitive HPV genotyping assay. J Clin Microbiol. 2010;48(1):143-9. https://doi.org/10.1128/JCM.0099109.

35. Mokili JL, Dutilh BE, Lim YW, Schneider BS, Taylor T, Haynes MR, Metzgar D, Myers CA, Blair PJ, Nosrat B, Wolfe ND, Rohwer F. Identification of a novel human papillomavirus by metagenomic analysis of samples from patients with febrile respiratory illness. PLoS One. 2013;8(3):e58404. https://doi.org/ 10.1371/journal.pone.0058404.

36. Hampras SS, Giuliano AR, Lin HY, Fisher KJ, Abrahamsen ME, Sirak BA, lannacone MR, Gheit T, Tommasino M, Rollison DE. Natural history of cutaneous human papillomavirus (HPV) infection in men: the HIM study. PLoS One. 2014;9(9):e104843. https://doi.org/10.1371/journal.pone.0104843.

37. Nunes EM, Sudenga SL, Gheit T, Tommasino M, Baggio ML, Ferreira S, Galan L, Silva RC, Pierce Campbell CM, Lazcano-Ponce E, Giuliano AR, Villa LL, Sichero L, group HIMS. Diversity of beta-papillomavirus at anogenital and oral anatomic sites of men: the HIM study. Virology. 2016;495:33-41. https:// doi.org/10.1016/j.virol.2016.04.031.

38. Kerge S, Vuorinen J, Hurme S, Soukka T, Gheit T, Tommasino M, Syrjanen S, Rautava J. Benign proliferative epithelial lesions of oral mucosa are infrequently associated with alpha-, beta-, or gamma human papillomaviruses. Laryngoscope Investig Otolaryngol. 2019;4(1):43-8. https:// doi.org/10.1002/lio2.222.

39. Dona MG, Chiantore MV, Gheit T, Fiorucci G, Vescio MF, La Rosa G, Accardi L, Costanzo G, Giuliani M, Romeo G, Rezza G, Tommasino M, Luzi F, Di Bonito P. Comprehensive analysis of beta- and gamma-human papillomaviruses in actinic keratosis and apparently healthy skin of elderly patients. Br J Dermatol. 2019;181(3):620-2. https://doi.org/10.1111/bjd.17836.

40. Gheit T, Billoud G, de Koning MN, Gemignani F, Forslund O, Sylla BS, Vaccarella S, Franceschi S, Landi S, Quint WG, Canzian F, Tommasino M. Development of a sensitive and specific multiplex PCR method combined with DNA microarray primer extension to detect Betapapillomavirus types. J Clin Microbiol. 2007;45(8):2537-44. https://doi.org/10.1128/JCM.00747-07. 
41. Moscicki AB, Ma Y, Gheit T, McKay-Chopin S, Farhat S, Widdice LE, Tommasino M. Prevalence and Transmission of Beta and Gamma Human Papillomavirus in Heterosexual Couples. Open Forum Infect Dis. 2017;4(1): ofw216. https://doi.org/10.1093/ofid/ofw216.

42. Gheit T, Anantharaman D, Holzinger D, Alemany L, Tous S, Lucas E, Prabhu PR, Pawlita M, Ridder R, Rehm S, Bogers J, Maffini F, Chiocca S, Lloveras B, Kumar RV, Somanathan T, de Sanjose S, Castellsague X, Arbyn M, Brennan P, Sankaranarayanan R, Pillai MR, Gangane N, Tommasino M. Role of mucosal high-risk human papillomavirus types in head and neck cancers in Central India. Int J Cancer. 2017;141(1):143-51. https://doi.org/10.1002/ijc.30712.

43. Klaes R, Friedrich T, Spitkovsky D, Ridder R, Rudy W, Petry U, DallenbachHellweg G, Schmidt D, von Knebel DM. Overexpression of p16(INK4A) as a specific marker for dysplastic and neoplastic epithelial cells of the cervix uteri. Int J Cancer. 2001;92(2):276-84. https://doi.org/10.1002/ijc.1174.

44. Hampras SS, Rollison DE, Giuliano AR, McKay-Chopin S, Minoni L, Sereday K, Gheit T, Tommasino M. Prevalence and concordance of cutaneous Beta human papillomavirus infection at mucosal and cutaneous sites. J Infect Dis. 2017;216(1):92-6. https://doi.org/10.1093/infdis/jix245.

45. De Vuyst $\mathrm{H}$, Clifford GM, Nascimento MC, Madeleine MM, Franceschi S. Prevalence and type distribution of human papillomavirus in carcinoma and intraepithelial neoplasia of the vulva, vagina and anus: a meta-analysis. Int J Cancer. 2009;124(7):1626-36. https://doi.org/10.1002/ijc.24116.

46. Sznurkowski JJ, Żawrocki A, Biernat W. The overexpression of p16 is not a surrogate marker for high-risk human papilloma virus genotypes and predicts clinical outcomes for vulvar cancer. BMC Cancer. 2016;16(1):465. https://doi.org/10.1186/s12885-016-2503-y.

47. Faber MT, Sand FL, Albieri V, Norrild B, Kjaer SK, Verdoodt F. Prevalence and type distribution of human papillomavirus in squamous cell carcinoma and intraepithelial neoplasia of the vulva: prevalence and type distribution of HPV in SCC and VIN. Int J Cancer. 2017;141(6):1161-9. https://doi.org/10. 1002/ijc.30821.

48. Mn S, Landolfi S, Olivella A, Lloveras B, Klaustermeier J, Surez H, Als L, LSM P-T, Campo E, Ordi J. p16 Overexpression Identifies HPV-positive Vulvar Squamous Cell Carcinomas. Am J Surg Pathol. 2006;30(11):1347-56. https:// doi.org/10.1097/01.pas.0000213251.82940.bf.

49. Riethdorf S, Neffen EF, Cviko A, Loning T, Crum CP, Riethdorf L. p16INK4A expression as biomarker for HPV 16-related vulvar neoplasias. Hum Pathol. 2004;35(12):1477-83.

50. Trietsch MD, Spaans VM, ter Haar NT, Osse EM, Peters AAW, Gaarenstroom KN, Fleuren GJ. CDKN2A (p16) and HRAS are frequently mutated in vulvar squamous cell carcinoma. Gynecol Oncol. 2014;135(1):149-55. https://doi. org/10.1016/j.ygyno.2014.07.094.

51. Malumbres M, Barbacid M. To cycle or not to cycle: a critical decision in cancer. Nat Rev Cancer. 2001;1(3):222-31. https://doi.org/10.1038/35106065.

\section{Publisher's Note}

Springer Nature remains neutral with regard to jurisdictional claims in published maps and institutional affiliations.

Ready to submit your research? Choose BMC and benefit from:

- fast, convenient online submission

- thorough peer review by experienced researchers in your field

- rapid publication on acceptance

- support for research data, including large and complex data types

- gold Open Access which fosters wider collaboration and increased citations

- maximum visibility for your research: over $100 \mathrm{M}$ website views per year

At BMC, research is always in progress.

Learn more biomedcentral.com/submissions 